\title{
Microhabitat segregation and physiological differences in two species of intertidal porcellanid crabs (Genus Petrolisthes) on the southern coast of Chile
}

\author{
MARCELO E. LAGOS, JOSÉ L. MUÑOZ, DANIELA A. CONTRERAS and \\ CRISTIAN W. CÁCERES \\ Departamento de Ecología Costera, Facultad de Ciencias, Universidad Católica Ssma. Concepción, \\ Alonso de Ribera 2850, Concepción Chile. E-mail: ccaceres@ucsc.cl
}

\begin{abstract}
SUMMARY: Intertidal crustaceans have a high degree of physiological plasticity, which allows them to withstand periods of water emersion. In this study we examine the physiological constraints that determine the distribution and abundance of the intertidal porcellanid crabs Petrolisthes laevigatus and Petrolisthes violaceus. This study evaluates the distribution and abundance of the two species at different tidal heights, in relation to haemocyanin concentration and LDH activity, resistance to air desiccation, thermal tolerance, and resistance to hypoxic water. The results showed that Petrolisthes laevigatus was more abundant at the high tide level than Petrolisthes violaceus, which was more abundant at the low tide level. Petrolisthes laevigatus showed greater tolerance to high temperatures and lower tolerance to desiccation when exposed to air than $P$. violaceus, which was also more tolerant to hypoxia during prolonged exposure. No differences were found in haemocyanin concentration and LDH activity. These findings support the idea of an evolutionary gradient towards terrestrial adaptations. Of the two species, Petrolisthes laevigatus showed the most advanced physiological features for semi-terrestrial specialization.
\end{abstract}

Keywords: zonation, desiccation, hypoxia, physiological tolerance, Petrolisthes, Chile.

\begin{abstract}
RESUMEN: DIFERENCIAS FISIOLÓGICAS Y SEGREGACIÓN DE MICROHÁBITAT EN DOS ESPECIES DE CRUSTÁCEOS PORCELÁNIDOS intermareales (GÉnero Petrolisthes) en la costa sur de Chile. - Los crustáceos intermareales poseen un alto grado de plasticidad fisiológica, lo que les permite soportar periodos prolongados de emersión. En este estudio se examinaron algunas restricciones fisiológicas que determinan la distribución y abundancia de los porcelánidos intermareales Petrolisthes laevigatus y Petrolisthes violaceus. En este estudio se evaluó la distribución de estas dos especies a diferentes niveles del intermareal, relacionándolos con la concentración de hemocianina y actividad de la enzima LDH, resistencia a la desecación, tolerancia termal y la resistencia a agua hipóxica. Los resultados mostraron una mayor abundancia de $P$. laevigatus en la zona alta del intermareal y de $P$. violaceus en la zona baja. $P$. laevigatus mostró una mayor tolerancia a altas temperaturas y una menor tolerancia a la desecación durante la exposición aérea que $P$. violaceus, que además fue mas tolerante a prolongadas exposiciones a la de hipoxia. No se encontraron diferencias en la concentración de hemocianina y actividad de LDH entre las especies. Estos resultados apoyan la idea de un gradiente evolutivo hacia la los sistemas terrestres. P. laevigatus mostró más adecuaciones fisiológicas para la especialización semi-terrestre.
\end{abstract}

Palabras clave: zonación, desecación, hipoxia, tolerancia fisiológica, Petrolisthes, Chile.

\section{INTRODUCTION}

Organisms inhabiting the intertidal zone are routinely exposed to environmental changes due to the tidal cycles and may sometimes spend $50 \%$ of their lives in semi-terrestrial conditions (Stillman and Somero,
1996). These conditions may include hours of air exposure, increased temperatures, and ambient hypoxia (Allen and Burnet, 2008).

Traditionally, the classic distribution patterns of intertidal organisms in discrete vertical zones have been explained as the interplay between abiotic factors (e.g. 
temperature, aerial exposure) (Connell, 1961; Somero, 2002) and biotic interactions (e.g. competition, predation). In general, abiotic factors are considered to be more important in the upper intertidal zone, whereas biotic factors are more relevant in the lower intertidal zone (Hofmann and Somero, 1995; Stillman and Somero, 1996; Somero, 2002; Stillman, 2002). In spite of these generalizations, there is only limited information on the physiological specializations that have allowed species with similar evolutionary histories to inhabit different positions in the intertidal zone.

Several lineages of benthic marine animals have made the evolutionary transition from aquatic to terrestrial habitats. When a change in habitat takes place, either on an evolutionary timescale for a particular lineage or on the current ecological timescale for an individual, the transition between two distinct physical environments, such as water and air, may have great molecular and physiological costs (Greenaway, 2003). We hypothesize that the position in the intertidal zone is representative of a species' position in the evolutionary transition from marine to land realms. Thus, the more advanced characteristics associated with terrestrial life, such as water conservation and temperature tolerance, should be present in species of the upper intertidal zone, and the more plesiomorphic characteristics associated with a mainly aquatic life should be observed in species characterizing the lower intertidal zone.

Porcelanid crabs are conspicuous organisms inhabiting the intertidal zone, with several species distributed along the Pacific coast of North and South America (Carvacho, 1980; Stillman and Reeb, 2001). For this group, life in the intertidal zone demands physiological and biochemical adaptations related to desiccation, temperature, and salinity tolerance, and the capability to withstand environmental variations (Jensen and Armstrong, 1991; Stillman and Somero, 1996; Yaikin et al., 2002). In terms of oxygen availability, changes in water temperature could affect the efficiency of capturing oxygen, and consequently provoke an increase in anaerobic metabolism, resulting in lactate accumulation (Stillman, 2000, Yaikin et al., 2002). To respond to these disturbances, organisms must change their physiology to modify their oxygen consumption, take oxygen from the environment and transport it efficiently to their tissues. One of these changes is the modification of the oxygen-haemocyanin binding affinities through an allosteric interaction with ions like lactate (Decker and Foll, 2000).

Intertidal porcelain crabs show wide differences in their tolerances to high temperatures. Research on Petrolisthes cinctipes, $P$. eriomerus and other species from the Porcellanidae family has shown that the upper tolerance limit of these species is very close to the temperature of their environment (Jensen and Armstrong, 1991; Somero, 2002; Stillman, 2003). In this sense, any modification in this variable due to macro-scale phenomena like global warming, could cause problems for the survival of these organisms (Helmuth et al., 2002).
Two common inhabitants of the Chilean shore are the Porcelain crabs Petrolisthes laevigatus and Petrolisthes violaceus (Viviani, 1969). These species exhibit different zonation patterns and degrees of exposure to terrestrial conditions. Petrolisthes laevigatus inhabits the upper intertidal zone, hiding underneath large rocks (Viviani, 1969). In contrast, $P$. violaceus inhabits the lower intertidal zone, immediately below $P$. laevigatus, down to the subtidal zone, where it is found underneath stones and on coarse sand (Viviani, 1969). Both species are likely to experience marked shifts in ambient temperature owing to variations in microhabitat isolation and tidal submersion/emersion patterns.

To test if differences in physiological responses are associated with their position in the intertidal zone, we evaluated differences in abundance of Petrolisthes laevigatus and $P$. violaceus at different intertidal heights in relation to their resistance to desiccation and the effects of high temperatures, the concentration of oxygen in the water, and also haemolymph physiology (LDH activity, haemocyanin concentration).

\section{MATERIALS AND METHODS}

This study was carried out in the rocky intertidal zone of Lenga, San Vicente Bay, Concepción, Chile $\left(36^{\circ} 45^{\prime} \mathrm{S} 73^{\circ} 10^{\prime} \mathrm{W}\right)$, during low tides in austral summer (January) 2004 (Fig. 1).

We sampled crab abundance under large rocks in the rocky intertidal zone. The density was measured during the daytime low tides along three five-meterlong transects perpendicular to the shoreline, extending from the water's edge to the upper intertidal zone, with $10 \mathrm{~m}$ between each transect. Along each transect, we measured crab density under rocks using $0.09 \mathrm{~m}^{-2}$ quadrants at five intertidal heights: $0.2,0.6,1.2,1.6$ and $2.0 \mathrm{~m}$ above mean low water (MLW).

For the experimental studies, similar sized animals, ranging between 12.9 and $19.5 \mathrm{~mm}$ cephalothorax length (CL), were collected at the study site and transported in refrigerated containers to the Physiology Laboratory of the Universidad Católica de la Santísima Concepción. In the laboratory, the animals were kept in individual aquaria and acclimated without food at $14^{\circ} \mathrm{C}$ for three days (Chen and Chia, 1997; Lucu and Devescovi, 1999, Castillo-Blasco et al., 2009), in filtered and aerated seawater. Following acclimatization, each animal was assigned to an experimental treatment.

To assess the effect of aerial exposure on the respiratory abilities of $P$. laevigatus and $P$. violaceus, we measured the haemolymphatic concentrations of haemocyanin and the activity of the lactate dehydrogenase enzyme (LDH). For this, 40 organisms of each species were placed in individual plastic containers $(500 \mathrm{~mL})$ at $14^{\circ} \mathrm{C}$ and assigned to four treatments: $(\mathrm{N}=10$ individuals per treatment) three different times of aerial exposure $(0,3$ and $6 \mathrm{~h})$ and a final treatment 


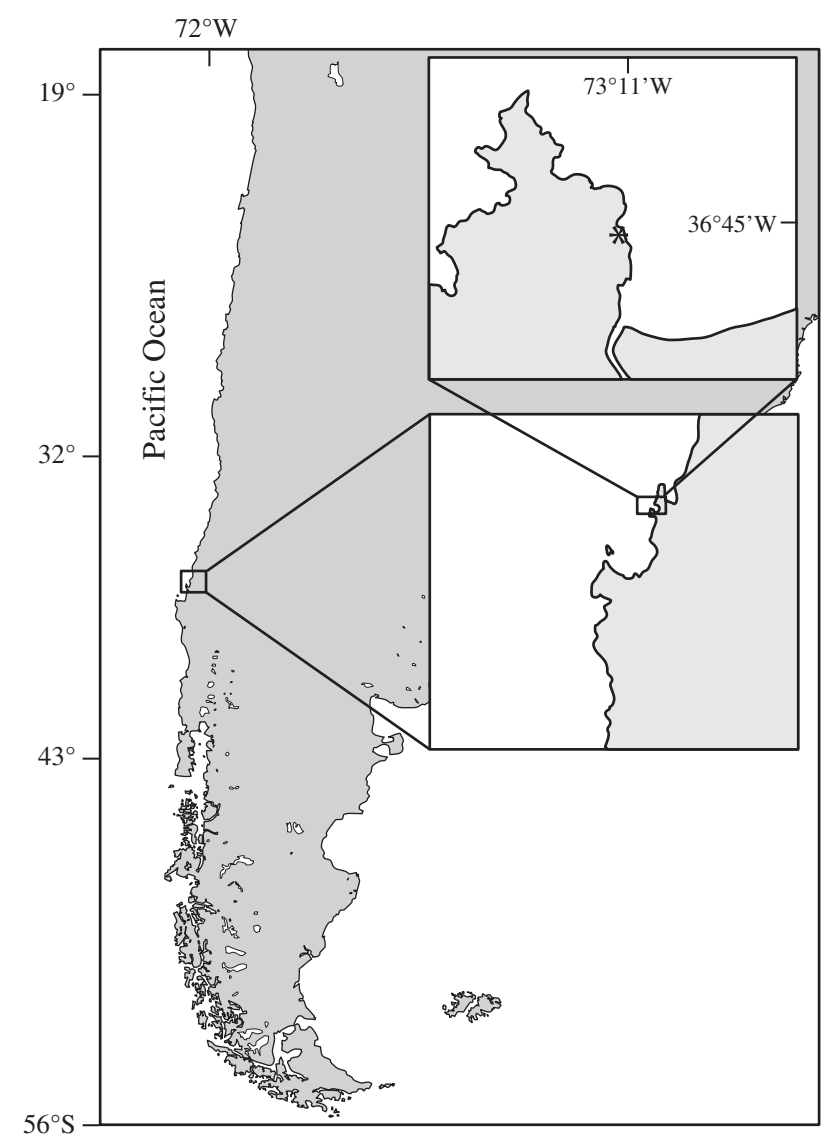

FIG. 1. - Map of the study site (asterisk) in Caleta Lenga (36 $45^{\prime} \mathrm{S}$ $\left.73^{\circ} 10^{\prime} W\right)$, San Vicente Bay, Chile.

of reimmersion in aerated sea water for $1 \mathrm{~h}$. Each individual was measured only once. Haemolymph was extracted from each specimen by puncturing the chelae with $1 \mathrm{~mL}$ syringes. The haemocyanin concentration was measured as described in Astete-Espinoza and Cáceres (2000); LDH concentrations were measured using the kinetic UV method (Gay et al., 1968).

To evaluate differences in the capacity for water conservation, we measured the water loss of the two species in aerial conditions. For this, 24 individuals of each species were weighed and placed in individual plastic containers at $15^{\circ} \mathrm{C}$ with a paper towel moistened with sea water, and exposed to emersion conditions for 1, 2, 4 and $6 \mathrm{~h}(\mathrm{~N}=6$ individuals per treatment) with a relative air humidity of $30-40 \%$. Individuals were weighed at the end of each experimental time. Afterwards, in order to estimate total water content, all individuals were dried in an oven for $48 \mathrm{~h}$ at $60^{\circ} \mathrm{C}$ until a constant weight was achieved.

The different water thermal tolerances of $P$. violaceus and $P$. laevigatus were evaluated by placing three replicates with 40 individuals of each species in $5 \mathrm{~L}$ containers with seawater in a thermoregulated bath $\left( \pm 1^{\circ} \mathrm{C}\right)$ at four experimental temperatures $(15,25$, $\left.30,35^{\circ} \mathrm{C}\right)$. To assess their capacity to tolerate water hypoxia, we used ten individuals of each species per treatment, which were exposed individually to three
TABle 1. - Mean abundance $( \pm \mathrm{SD})$ of Petrolisthes laevigatus and $P$. violaceus at different levels of intertidal zone at Caleta Lenga $\left(36^{\circ} 45^{\prime} \mathrm{S} 73^{\circ} 10^{\prime} \mathrm{W}\right)$.

\begin{tabular}{lcc}
\hline Intertidal height $(\mathrm{m})$ & \multicolumn{2}{c}{ Abundance $\left(\right.$ ind. $\left.\mathrm{m}^{-2}\right)$} \\
& P. laevigatus & P. violaceus \\
\hline 0.2 & $25.9 \pm 3.7$ & $706.7 \pm 134.7$ \\
0.6 & $318.2 \pm 124.3$ & $636.4 \pm 157.5$ \\
1.2 & $610.5 \pm 83.3$ & $214.6 \pm 48.5$ \\
1.6 & $1206.2 \pm 403.8$ & $321.9 \pm 52.4$ \\
2 & $799.2 \pm 221.1$ & $3.7 \pm 3.7$ \\
\hline
\end{tabular}

TABLE 2. - Average values of haemocyanin concentration and $\mathrm{LDH}$ activity at different times of aerial exposure and reimmersion (average $\pm \mathrm{SD}$ ).

\begin{tabular}{|c|c|c|c|c|}
\hline Time (h) & 0 & 3 & 6 & reimmersion \\
\hline \multicolumn{5}{|l|}{$\begin{array}{l}\text { LDH Activity } \\
\text { (UI } \mathrm{mL}^{-1} \text { ) }\end{array}$} \\
\hline P. laevigatus & $2.70 \pm 0.72$ & $2.75 \pm 0.81$ & $3.05 \pm 0.35$ & $2.85 \pm 0.66$ \\
\hline P. violaceus & $2.93 \pm 0.29$ & $3.05 \pm 0.29$ & $2.93 \pm 0.37$ & $3.19 \pm 0.13$ \\
\hline \multicolumn{5}{|c|}{$\begin{array}{l}\text { Haemocyanin concentration } \\
\left(\mu \mathrm{mol} \mathrm{mL} \mathrm{mL}^{-1}\right)\end{array}$} \\
\hline P. laevigatus & $4.52 \pm 1.24$ & $4.53 \pm 1.46$ & $5.12 \pm 0.63$ & $4.86 \pm 1.19$ \\
\hline P. violaceus & $4.93 \pm 0.59$ & $5.13 \pm 0.52$ & $5.40 \pm 0.23$ & $4.52 \pm 1.24$ \\
\hline
\end{tabular}

different water-oxygen concentrations: $1.0 \mathrm{mg} \mathrm{O}_{2} \mathrm{~L}^{-1}$ (low), $2.5 \mathrm{mg} \mathrm{O}_{2} \mathrm{~L}^{-1}$ (medium), and $5.5 \mathrm{mg} \mathrm{O}_{2} \mathrm{~L}^{-1}$ (high) in $500 \mathrm{~mL}$ chambers. At the end of each experiment the criteria for survival was the presence of antennal movements (Haye and Ojeda, 1998).

\section{Statistical analysis}

For each species, the relationship between intertidal height and species abundance was evaluated using Pearson correlation coefficients (Zar, 1996). The variations in haemocyanin concentration, LDH activity, temperature and hypoxia tolerance were analyzed by fixed, two-way or three-way ANOVA models, using species, time, temperature or oxygen concentration as fixed factors. Data were normal and homoscedastic following logarithmic transformation. When significant differences were detected, a posteriori comparisons were made with Tukey's test (Zar, 1996).

\section{RESULTS}

Both species showed different patterns of density along the intertidal zone. Petrolisthes violaceus was most abundant $\left(706.7 \pm 134.7\right.$ ind $\left.\mathrm{m}^{-2}\right)$ at $0.2 \mathrm{~m}$ over MLW and least abundant at $2 \mathrm{~m}$ over MLW $\left(3.7 \pm 3.7\right.$ ind $\left.\mathrm{m}^{-2}\right)(\mathrm{r}=-0.83, \mathrm{p}<0.01)$. In contrast, $P$. laevigatus was most abundant in the upper intertidal zone at 1.6 and $2.0 \mathrm{~m}$ over MLW (1206.2 \pm 403.81 and $799.2 \pm 221.16$ ind $\mathrm{m}^{-2}$ ) and its density decreased with the tidal level $\left(25.9 \pm 3.7\right.$ ind $\mathrm{m}^{-2}$ at $0.2 \mathrm{~m}$ over MLW) (Table 1) $(\mathrm{r}=0.69, \mathrm{p}<0.01)$.

In experiments of aerial exposure followed by reimmersion, the haemocyanin concentration and LDH activity did not show differences among species, time 


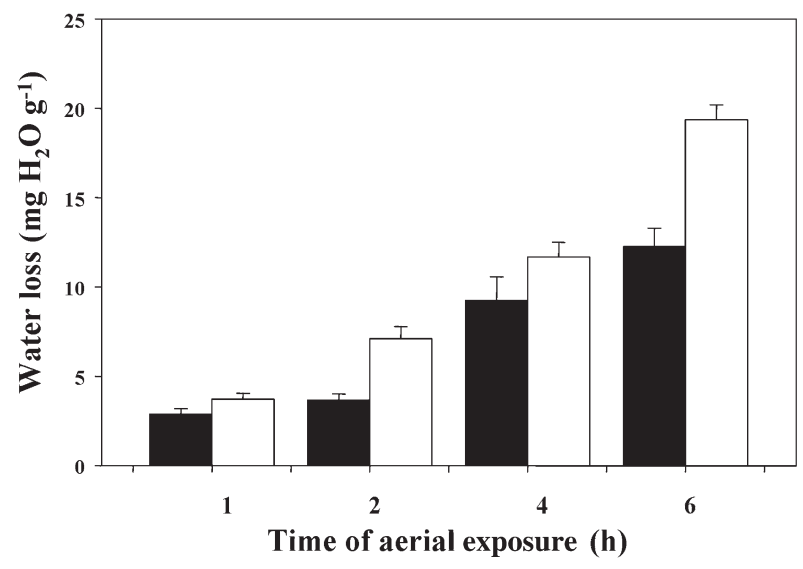

FIg. 2. - Mean water loss of Petrolisthes violaceus (white bars) and $P$. laevigatus (black bars) over different times of aerial exposure $(\mathrm{x} \pm \mathrm{SE})$.

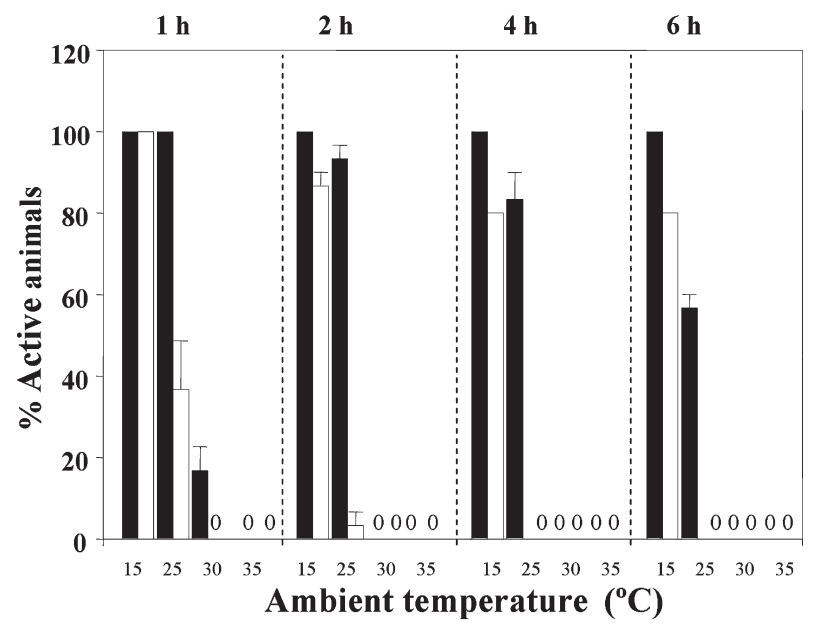

FIG. 3. - Observed activity of Petrolisthes violaceus (white bars) and P. laevigatus (black bars) over time at different temperatures $(\mathrm{x} \pm \mathrm{SE})$.

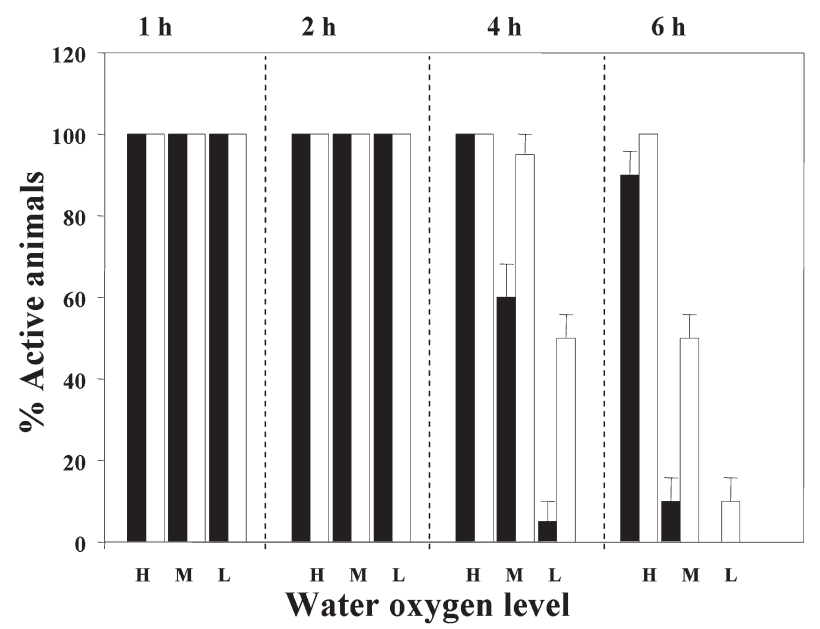

FIG. 4. - Observed activity of Petrolisthes violaceus (white bars) and $P$. laevigatus (black bars) over time at different water oxygen concentrations $(\mathrm{x} \pm \mathrm{SE})$. L, low oxygen concentration: $(1.0 \mathrm{mg} \mathrm{O}$ $\left.\mathrm{L}^{-1}\right) ; \mathrm{M}$, medium oxygen concentration $\left(2.5 \mathrm{mg} \mathrm{O}_{2} \mathrm{~L}^{-1}\right)$; and $\mathrm{H}$, high oxygen concentration $\left(5.5 \mathrm{mg} \mathrm{O}_{2} \mathrm{~L}^{-1}\right)$. or an interaction between the two factors (Table 2), and had mean values of $4.52 \pm 1.24 \mu \mathrm{mol} \mathrm{mL} \mathrm{m}^{-1}$ for haemocyanin concentration and $2.70 \pm 0.72 \mathrm{UI} \mathrm{mL}^{-1}$ for $\mathrm{LDH}$ activity.

The initial body water content was similar in the two species, averaging $59.97 \pm 0.67 \%$. In the desiccation experiments, the two species had different capacities for tolerating aerial exposure, and $P$. violaceus showed the greater water loss (Fig. 2). The emersion time was a significant factor for water loss. The statistical analysis showed an interaction between species and time (Table $3 \mathrm{c}$ ), in which $P$. violaceus at $6 \mathrm{~h}$ of emersion was the group with the highest water loss (Fig. 2).

The results of the thermal tolerance experiments revealed differences between species, temperature and time, and $P$. laevigatus was less susceptible than $P$. violaceus to temperature. No activity (as defined above) was observed over $30^{\circ} \mathrm{C}$ in $P$. violaceus or over $35^{\circ} \mathrm{C}$ in $P$. laevigatus (Tukey a posteriori $\mathrm{p}<0.05$ ). The three-way variance analysis showed a strong effect of factors (species, time, temperature), an interaction between time and temperature, and between all three factors (Fig. 3, Table 3d). In the water hypoxia experiments, the three factors showed statistically significant effects. Petrolisthes violaceus showed a greater ca-

TABLE 3. - Statistical analyses for each variable under study. P, probability value $\mathrm{P}<0.05$.

\begin{tabular}{|c|c|c|c|c|}
\hline & DF & MS & $\mathrm{F}$ & $\mathrm{p}$ \\
\hline \multicolumn{5}{|c|}{ a) Haemocyanin concentration } \\
\hline Species & 1 & 0.372 & 1.423 & 0.241 \\
\hline Time & 3 & 0.087 & 0.334 & 0.800 \\
\hline Species*time & 3 & 0.114 & 0.438 & 0.726 \\
\hline Error & 32 & 0.262 & & \\
\hline \multicolumn{5}{|l|}{ b) $\mathrm{LDH}$} \\
\hline Species & 1 & 0.553 & 0.570 & 0.455 \\
\hline Time & 3 & 0.685 & 0.706 & 0.555 \\
\hline Species*time & 3 & 0.413 & 0.425 & 0.735 \\
\hline Error & 32 & 0.970 & & \\
\hline \multicolumn{5}{|l|}{ c) Water loss } \\
\hline Species & 1 & 143.707 & 38.371 & $<0.001$ \\
\hline Time & 3 & 375.089 & 100.151 & $<0.001$ \\
\hline Species*time & 3 & 21.28 & 56.819 & 0.002 \\
\hline Error & 40 & 3.745 & & \\
\hline \multicolumn{5}{|l|}{ d) Thermal tolerance } \\
\hline Species & 1 & 2.976 & 280.363 & $<0.001$ \\
\hline Time & 3 & 0.301 & 28.344 & $<0.001$ \\
\hline Temp. & 3 & 10.279 & 968.282 & $<0.001$ \\
\hline $1 * 2$ & 3 & 0.017 & 1.643 & 0.188 \\
\hline $1 * 3$ & 3 & 1.342 & 126.435 & $<0.001$ \\
\hline $2 * 3$ & 9 & 0.092 & 8.690 & $<0.001$ \\
\hline $1 * 2 * 3$ & 9 & 0.043 & 4.031 & $<0.001$ \\
\hline Error & 64 & 0.011 & & \\
\hline \multicolumn{5}{|c|}{ e) Water oxygen concentration } \\
\hline Species & 1 & 0.627 & 50.270 & $<0.001$ \\
\hline Time & 3 & 3.618 & 290.100 & $<0.001$ \\
\hline Oxygen & 2 & 3.007 & 241.110 & $<0.001$ \\
\hline $1 * 2$ & 3 & 0.237 & 18.980 & $<0.001$ \\
\hline $1 * 3$ & 2 & 0.157 & 12.550 & $<0.001$ \\
\hline $2 * 3$ & 6 & 1.082 & 86.760 & $<0.001$ \\
\hline $1 * 2 * 3$ & 6 & 0.076 & 6.080 & $<0.001$ \\
\hline Error & 70 & 0.013 & & \\
\hline
\end{tabular}


pacity to maintain its activity in hypoxic waters than $P$. laevigatus, with significantly higher activity in all oxygen concentrations (Tukey a posteriori $\mathrm{p}<0.001$ ). At medium and low oxygen concentrations, and for an exposure time greater than $4 \mathrm{~h}, P$. laevigatus did not show observable movements (Tukey a posteriori ) (Fig. 4, Table 3e).

\section{DISCUSSION}

In agreement with previous reports, our results showed an evident spatial segregation in abundance between $P$. laevigatus and $P$. violaceus. On average, $P$. laevigatus was the most abundant species in the upper intertidal zone. In contrast, the maximum density of $P$. violaceus was found in the lower intertidal zone. These opposing distribution patterns can be attributed mainly to differences in the physiological capacity of each species to cope with desiccation, anoxia, and temperature in both aquatic and aerial environments. This predominance of physiological limits over biotic interactions (sensu Connell, 1961) in determining the distribution of congeneric species inhabiting the same area has been reported in other field studies with porcelanids, although only the limitation in the colonization of the upper intertidal by the low intertidal species was attributed to physiological constraints (Jensen and Armstrong, 1991).

The lack of differences in the haemolymphatic haemocyanin concentration and LDH activity in emersion and subsequent immersion could indicate the physiological capability of the two species to tolerate transient air exposure without falling into metabolic decompensation. This could be due to air respiration through membranous gas windows on the walking legs (Stillman and Somero, 1996, Stillman 2000). Vargas et al. (2010) reported that aerial exposure in P. laevigatus and $P$. violaceus is altered by their physiological homeostasis, producing haemolymphic acidification, by which $P$. violaceus is the most affected. Considering this, although the haemocyanin concentration was not negatively affected, there is probably an alteration in the oxygen-haemocyanin binding affinities, which are moderated through an allosteric interaction with inorganic ions and other effectors such as protons; this modification can help to maintain an adequate oxygen supply to the tissue (Powell and Watts 2006).

Water loss for P. laevigatus was significantly lower than for $P$. violaceus. This difference between species inhabiting low and high intertidal zones has been described for other crab species (Jones and Greenwood, 1982) and attributed to local differences in air humidity along intertidal levels caused by the effect of waves and tidal rhythms. In this work, we did not measure the effect of wind on evaporative water loss, although the general trend should be similar to that found in the laboratory experiments. The differences in water loss are congruent with the increased capacity for the intertidal species, $P$. laevigatus, to tolerate aerial exposure.
We believe that resistance to desiccation is an important factor that determines fitness in environments with low water availability or air with low water saturation. These differences could be associated with difference in exoskeleton permeability or a more efficient chemical mechanism of water conservation in P. laevigatus. In addition, these species have different behavioural characteristics, and Petrolisthes laevigatus is less active and less aggressive than $P$. violaceus (M. Lagos, pers. obs.). Several other studies (Vannini and Ferretti, 1997; Greenaway, 2003) have interpreted these differences in activity as a mechanism for minimizing water loss, which could complement the physiological rates of water loss. In our results, $P$. laevigatus, the species that inhabits the upper intertidal zone, showed a greater capacity for coping with thermal stress than $P$. violaceus. In the $25^{\circ} \mathrm{C}$ aerial exposure experiments, the latter species was inactive after a short time (2 h), whereas $P$. laevigatus withstood $6 \mathrm{~h}$ under these conditions. Neither species survived over $1 \mathrm{~h}$ under conditions over $30^{\circ} \mathrm{C}$. Stillman and Somero (2001) reported $50 \%$ mortality of the same species at $30^{\circ} \mathrm{C}$ over an aerial exposure period of $8 \mathrm{~h}$. These authors used specimens from a site near Valparaiso $\left(33^{\circ} 01^{\prime} \mathrm{S}\right.$, $71^{\circ} 38^{\prime} \mathrm{O}$ ), about $500 \mathrm{~km}$ north of our study site, where the mean maximum temperature in summer is about $30^{\circ} \mathrm{C}$, whereas the maximum summer temperature in Concepción is around $25^{\circ} \mathrm{C}$. In all cases, these species live in conditions near their tolerance limits, and consequently are very susceptible to major climate changes such as global warming (Helmuth et al., 2002; Stillman, 2003).

The current increases in global mean temperature produced by global warming could lead to a higher frequency and severity of heat waves. These phenomena may be a strong selective agent in intertidal animals, because their upper limits of distribution are linked with their ability to survive in extreme thermal events (Harley, 2008; Stillman and Tagmount, 2009). How the fitness and distribution of these organisms will change under the current scenario of climate change will depend on their ability to acclimatize and adapt to the increases in the extreme hot weather events that are likely to occur (Somero 2002; Stillman, 2003; Stillman and Tagmount, 2009).

Our experiments showed different capacities for living in aquatic environments. The crab from the low intertidal zone, $P$. violaceus, was better able to cope with water hypoxia than $P$. laevigatus; this capacity is a key factor for an organism that lives mainly in marine water due to its position in the lower intertidal zone. We speculate that in aquatic conditions, $P$. violaceus probably has an oxyconformer strategy, adapting to the oxygen demand without compromising its survival in an oxygen fluctuating environment. In addition, changes in $\mathrm{pH}$ associated with aerial exposure (Lagos and Cáceres, 2008) could be related to change in the haemocyanin carrying capacity (Bohr effect) during hypoxic periods (Truchot, 1980). No inactivity was 
observed in either species during the first two hours of exposure to water hypoxia. In the following hours, the percentage of individuals without observable activity was higher in $P$. laevigatus. This indicates the capacity of $P$. violaceus to spend longer periods of time in water hypoxia (Yaikin et al., 2002).

Finally, it is necessary to carry out further studies of the ways in which the whole-organism physiology can provide insights into the underlying mechanisms and consequences of environmental change in a macrophysiological context. This means investigating the variation in physiological traits over large geographical and temporal scales and understanding the ecological implications of this variation.

\section{REFERENCES}

Allen, S.M. and L.E. Burnett. - 2008. The effects of intertidal air exposure on the respiratory physiology and the killing activity of hemocytes in the pacific oyster, Crassostrea gigas (Thunberg). J. Exp. Mar. Biol. Ecol., 357(2): 165-171.

Astete-Espinoza, L.P. and C.W. Cáceres. - 2000. Efecto del parasitismo del isópodo bopírido Ionella agassizi (Isopoda: Epicaridea) (Bornnier, 1990) sobre la fisiología nutricional del nape Neotripaea unsinata (M. Edwards, 1837) (Decapoda: Thalassianidea). Rev. Chil. Hist. Nat., 73: 243-252.

Carvacho, A. - 1980. Los porcelánidos del pacífico americano: Un análisis biogeográfico (Crustacea: Decapoda). An. Centro Cienc. Del Mar y Limnol. Univ. Nal. Autón. México, 7: 249-258.

Castillo-Blasco, C.A., M.E. Lagos and C.W. Cáceres. - 2009. Osmoregulación y equilibrio ácido-base en el crustáceo Neotrypaea uncinata (Milne Edwards, 1837) (Decapoda: Thalassinidae): consecuencias del parasitismo por Ionella agassizi (Bonnier, 1900) (Isopoda: Bopyridae). Rev. Biol. Mar. Oceanogr., 44(3): 715-724.

Chen, J.C. and P.G. Chia. - 1997. Osmotic and ionic concentrations of Scylla serrata (Porskal) subjected to different salinity levels. Comp. Biochem. Physiol. A, 117: 239-244.

Connell, J.H. - 1961. Effects of competition, predation by Thais lapillus and other factors on natural populations of the barnacle Balanus balanoides. Ecol. Monogr., 31: 51-104.

Decker, H. and R. Foll. - 2000. Temperature adaptation influences the aggregation state of hemocyanin from Astacus leptodactylus. Comp. Biochem. Physiol. A, 127: 147-154.

Gay, R.J., R.B. McComb and G.N. Bowers. - 1968. Optimum reaction conditions for human lactate dehydrogenase isoenzymes as they affect total lactate dehydrogenase activity. Clin. Chem., 14: 740-753.

Greenaway, P. - 2003. Terrestrial adaptation in the Anomura (Crustacea: Decapoda). Mem. Natl. Mus., Victoria, 60: 13-26.

Harley, C.D.G. - 2008. Tidal dynamics, topographic orientation, and temperature-mediated mass mortalities on rocky shores. Mar. Ecol. Prog. Ser., 371: 37-46.

Haye, P.H. and F.P. Ojeda. - 1998. Metabolic and behavioural alterations in the crab Hemigrapsus crenulatus (Milne-Edwards 1837) induced by its acanthocephalan parasite Profilicollis antarcticus (Zdzitowiecki 1985). J. Exp. Mar. Biol. Ecol., 228: $73-82$.

Helmuth, B., C.D. Harley, P.M. Halpin, M. O'Donnell, G.E. Hofmann and C.A. Blanchette. - 2002. Climate change and latitudinal patterns of intertidal thermal stress. Science, 298: 1015-1017.

Hofmann, G.E. and G.N. Somero. - 1995. Evidence for protein damage at environmental temperatures: seasonal changes in levels of ubiquitin conjugates and hsp70 in the intertidal mussel Mytilus trossulus. J. Exp. Biol., 198: 1509-1518.

Jensen, G.C. and D.A. Armstrong. - 1991. Intertidal zonation among congeners: factors regulating distribution of Porcelain crabs Petrolisthes spp. (Anomura: Porcellanidae). Mar. Ecol. Prog. Ser., 73: 47-60.

Jones, M.B. and J.G. Greenwood. - 1982. Water loss of a Porcelain crab, Petrolisthes elongatus (Milne Edwards, 1837) (Decapoda, Anomura) during atmospheric exposure. Comp. Biochem. Physiol. B., 72: 631-636.

Lagos, M.E. and C.W. Cáceres. - 2008. Como afecta la exposición aérea el equilibrio ácido base de organismos móviles del intermareal: Petrolisthes laevigatus (Guérin, 1835) (Decapoda: Porcellanidae) como caso de estudio. Rev. Biol. Mar. Oceanogr., 43: 591-598.

Lucu, C. and M. Devescovi. - 1999. Osmoregulation and branchial $\mathrm{Na}^{+}, \mathrm{K}^{+}$-ATPase in the lobster Homarus gammarus acclimated to dilute seawater. J. Exp. Mar. Biol. Ecol., 234: 291-304.

Powell, M. L. and S. A. Watts. - 2006. Effect of temperature acclimation on metabolism and hemocyanin binding affinities in two crayfish, Procambarus clarkii and Procambarus zonangulus. Comp. Biochem. Physiol. A, 144: 211-217.

Somero, G.N. - 2002. Thermal physiology and vertical zonation of intertidal animals: Optima, limits, and costs of living. Integ. Comp. Biol., 42: 780-789.

Stillman, J.H. - 2000. The evolutionary history and adaptive significance of secondary respiratory structures in intertidal crabs: relationships with body size and vertical distribution. Physiol. Biochem. Zool., 73: 86-96.

Stillman, J.H. - 2002. Causes and consequences of thermal tolerance limits in rocky intertidal porcelain crabs, Genus Petrolisthes. Integ. and Comp. Biol., 42: 790-796.

Stillman, J.H. - 2003. Acclimation capacity underlies climate change susceptibility. Science, 301: 65.

Stillman, J.H. and G.N. Somero. - 1996. Adaptations to temperature stress and aerial exposure in congeneric species of intertidal porcelain crabs (genus Petrolisthes): correlation of physiology, biochemistry and morphology with vertical distributions. J. Exp. Biol., 199: 1845-1855.

Stillman, J.H. and C.A. Reeb. - 2001. Molecular phylogeny of Eastern Pacific porcelain crabs, genera Petrolisthes and Pachycheles, Based on the mtDNA 16S rDNA. Mol. Phylogenet. Evol., 19(2): 236-245.

Stillman, J.H. and G.N. Somero. - 2001. A comparative analysis of the upper thermal tolerance limits of eastern pacific porcelain crabs, genus Petrolisthes: Influences of latitude, vertical zonation, acclimation, and phylogeny. Physiol. Biochem. Zool., 73: 200-208.

Stillman, J.H. and A. Tagmount. - 2009. Seasonal and latitudinal acclimatization of cardiac transcriptome responses to thermal stress in porcelain crabs, Petrolisthes cinctipes. Mol. Ecol., 18: 4206-4226.

Truchot, J.P. - 1980. Lactate increases the oxygen affinity of crab hemocyanin. J. Exp. Zool., 214: 205-208.

Vannini, M. and J. Ferretti. - 1997. Chemoreception in two species of terrestrial hermit crabs (Decapoda: Coenobitidae). J. Crustac. Biol., 17: 33-37.

Viviani, C.A. - 1969. Los Porcellanidae (Crustacea, Anomura) chilenos. Beitr. Zool. Vergleich., 6: 40-56.

Yaikin, J., R.A. Quiñónez and R.R. González. - 2002. Aerobic respiration rate and anaerobic enzymatic activity of Petrolisthes laevigatus (Anomura, Porcellanidae) under laboratory conditions. J. Crustac. Biol., 22: 345-352.

Zar, J.H. - 1996. Biostatistical analysis. Prentice Hall, Englewood Cliffs.

Scient. ed.: F. Maynou.

Received February 23, 2010. Accepted September 14, 2010.

Published online March 10, 2011. 